\title{
Inhibitory Effects and Killing Kinetics of Lactic Acid Rice Gel Against Pathogenic Bacteria Causing Bovine Mastitis
}

\author{
Rinrada Chotigarpa ${ }^{1}$, Kannika Na Lampang ${ }^{1}$, Surachai Pikulkaew ${ }^{2,3}$, Siriporn Okonogi ${ }^{3,4}$, \\ Kittisak Ajariyakhajorn 5 (iD) and Raktham Mektrirat ${ }^{1,3, * \text { (ID }}$ \\ 1 Department of Veterinary Biosciences and Public Health, Faculty of Veterinary Medicine, \\ Chiang Mai University, Chiang Mai 50100, Thailand; rchotigarpa@gmail.com (R.C.); \\ kna_lampang@hotmail.com (K.N.L.) \\ 2 Department of Food Animal Clinic, Faculty of Veterinary Medicine, Chiang Mai University, \\ Chiang Mai 50100, Thailand; surapikulkaew@gmail.com \\ 3 Research Center of Pharmaceutical Nanotechnology, Chiang Mai University, Chiang Mai 50200, Thailand; \\ okng2000@gmail.com \\ 4 Department of Pharmaceutical Sciences, Faculty of Pharmacy, Chiang Mai University, \\ Chiang Mai 50200, Thailand \\ 5 Department of Veterinary Medicine, Faculty of Veterinary Science, Chulalongkorn University, \\ Bangkok 10330, Thailand; kittisak_cu@yahoo.com \\ * Correspondence: raktham.m@cmu.ac.th; Tel.: +66-(53)-948026; Fax: +66-(53)-274710
}

Received: 13 June 2018; Accepted: 11 July 2018; Published: 16 July 2018

\begin{abstract}
Staphylococcus aureus and S. epidermidis are the major teat skin bacteria and lead to severe bovine mastitis. Teat antiseptic is an important tool for controlling intramammary infection. The antibacterial activity of lactic acid (LA) against one reference strain of S. aureus ATCC 25923 and two field strains including S. aureus and S. epidermidis was investigated using the broth microdilution method. Its minimum inhibitory concentration (MIC) and minimum bactericidal concentration (MBC) were $0.5 \%$ for strains belonging to both species. An antiseptic preparation containing $5 \%$ LA with modified rice gel (LA-RG) was successfully prepared. Rheological behavior of LA-RG was found to be a pseudoplastic flow with thixotropy with viscosity of approximately 0.007 Pas. LA-RG exhibited a sufficient adhesive property in the rolling ball test with a length of $9.67 \pm 0.04 \mathrm{~cm}$. Killing kinetic studies of LA-RG showed that the killing rate of LA-RG was significantly faster than that of LA. After 32 min of exposure to LA-RG, approximately $86 \%$ and $60 \%$ of S. aureus and S. epidermidis were reduced, respectively. Abnormal bacterial cell surface after exposure to LA-RG was observed by scanning electron microscopy. It is concluded that LA-RG is a promising preparation as an alternative product for preventing mastitis in dairy cattle.
\end{abstract}

Keywords: rice; antiseptic; teat skin; lactic acid

\section{Introduction}

The cutis is colonized by several types of epidermal flora including commensal and pathogenic bacteria. The different staphylococcal species are common colonizers of mammal skin [1]. Bacterial skin infections are usually caused by staphylococcal species [2]. The staphylococcal species are increasing their resistance to different antibiotics and the important causal agent of subclinical bovine mastitis $[3,4]$. In Thailand, the prevalence of subclinical mastitis is $75.0-83.3 \%$ and a prior study found that the prevalence of intramammary infection of $S$. aureus and coagalase-negative staphylococci (CNS) was $3.5-11.8 \%$ and $13.1-27.0 \%$, respectively $[5,6]$. S. aureus is one of the most important contagious bacterial 
causes of subclinical bovine mastitis [7]. S. epidermidis was a major etiological agent of persistent intramammary infection in multiparous cows and a very common pathogen in the CNS bacteria group [8,9]. Bacterial colonization of teat skin is able to invade the mammary gland during the milking process. This situation is not only a great cause of economic loss and affects milk components, it is also a serious public health problem. The prevention of epidermal bacterial transmission depends mostly on effective skin hygiene and antiseptic products [10]. In the market, many different products with various active ingredients are available. Most of the active ingredients are chemical agents, which come with a risk of skin irritation and cause bacterial resistance [11]. Therefore, preparations of natural products offer attractive alternative remedies.

Interestingly, lactic acid or 2-hydroxypropanoic acid is used in food and cosmetics as preservatives [12]. It has been reported that lactic acid has antibacterial activities against certain Gram positive and Gram negative bacteria [13]. Moreover, lactic acid is also safe for skin and has emollient properties making it suitable for topical preparation [14]. However, the efficacy of organic antiseptic requires exposure to the product by adherence to the lesion for a long time. Therefore, many efforts are being made to discover potential natural gelling agents. Gel preparation is one of the most preferable among several local dosage forms used in topical medication because of its excellent adhesiveness, comfort and easy removal throughout the epidermis. Moreover, topical gels exhibit prolonged residence time at the site of drug action on the epidermal surface [15].

Thailand is a major producer and a world exporter of rice grain (Oryza sativa L.). Attempts have recently been made to turn this agricultural product into value-added pharmaceutical materials. The polysaccharide from rice starch was previously isolated and chemically modified [16]. Interestingly, the physicochemical characteristics of the modified rice powders can be feasibly made into good gelling agents in pharmaceutical gel preparation [17]. Hence, in developing antiseptic preparations, loading lactic acid into modified rice gel should have more advantage for biological and pharmaceutical aspects than synthetic chemical products. The main aim of the present study is an attempt to evaluate pharmaceutical gel preparation containing a biodegradable materials carrier (modified rice gel) and the natural antibacterial agent (lactic acid) on the epidermal surface. In order to achieve this aim, the antibacterial activity and the killing kinetic of lactic acid rice gel against bovine mastitis pathogenic staphylococci were investigated. Scanning electron microscopy (SEM) was used to identify cell morphology and membrane structure which could confirm the antibacterial property of the preparation.

\section{Materials and Methods}

\subsection{Materials}

Milled rice grains were obtained from a harvest during April-September 2016. Lactic acid and monochloroacetic acid were purchased from Sigma-Aldrich (St. Louis, MO, USA). Blood agar base (BA), Muller Hinton agar (MHA), Muller Hinton broth (MHB), plate count agar (PCA), tryptic soy agar (TSA) and tryptic soy broth (TSB) were obtained from Merck (Darmstaadt, Germany). All other chemicals and solvents were of analytical grade.

\subsection{Bacterial Strains}

The standard strains of S. aureus ATCC 25923 and the field isolates of skin bacteria including S. aureus and S. epidermidis were provided by the Faculty of Veterinary Medicine, Chiang Mai University, Thailand.

\subsection{Minimum Inhibitory Concentration (MIC) and Minimum Bactericidal Concentration $(\mathrm{MBC})$ Determination}

A solution of $10 \% v / v$ lactic acid was freshly prepared by dissolving the exact amount of lactic acid in sterile distilled water. The series of ten-fold dilution of various concentrations $(10,5,1,0.5$, 
$0.1 \% v / v$ ) of lactic acid in sterile distilled water was prepared. An in vitro broth microdilution test was carried out to determine the MIC and MBC of lactic acid against standard S. aureus ATCC 25923 and the field strains consisted of 3 epidemiologically unrelated isolates of $S$. aureus and 3 isolates of S. epidermidis. The bacteria cells were cultured in TSA plates containing 5\% sheep blood, following the National Committee for Clinical Laboratory Standards (NCCLS) recommendation. The bacterial colonies from the agar medium were suspended in MHB and the turbidity was adjusted equivalent to a $0.5 \mathrm{McF}$ arland standard before use. A sterile 96 well plate containing equal volumes of bacterial suspension and various concentrations of lactic acid was incubated at $37^{\circ} \mathrm{C}$ for $24 \mathrm{~h}$. The MIC value was determined by observing the bacterial growth in the visual medium turbidity. The MBC value was determined for MHA by using the drop plate technique. The lowest lactic acid concentration that could completely inhibit bacterial growth, after incubating at $37^{\circ} \mathrm{C}$ for $24 \mathrm{~h}$, is the MBC value [18]. The MIC and MBC assays of each strain were run in duplicate.

\subsection{Preparation of Modified Rice Gel Containing Lactic Acid}

The powder of milled rice grains was subjected to a chemical modification method described previously [16]. Briefly, the rice powder was subjected to etherification in a mixture of methanol-water medium. The proper amount of monochloroacetic acid was gradually added. The mixture was continuously stirred at $60^{\circ} \mathrm{C}$ for $3 \mathrm{~h}$. The solid phase obtained was washed with $95 \%$ ethanol then dried and pulverized. The modified rice powder, passed through an 80-mesh sieve, was used for gel base preparation. An aqueous solution of lactic acid was prepared using the appropriate amount of polysorbate 80 as a solubilizing agent and modified rice gel as a viscosity building agent. Then, purified water was added to adjust the final concentration of lactic acid to $5 \% v / v$. The mixture was gently stirred and then subjected to a high shear mixing device (Ultra-Turrax T25, IKA, Staufen im Breisgau, Germany) at high-speed stirring of $5000 \mathrm{rpm}$ for $1 \mathrm{~min}$. The obtained gel was subjected to an autoclave for final sterilization.

\subsection{Characterization of the Gel Formulation}

The product was first examined for contaminated bacteria. The $\mathrm{pH}$ of the formulation was measured using $\mathrm{pH}$ meter (Mettler Toledo, Greifensee, Switzerland) and the turbidity was measured using a spectrophotometer (JASCO Corporation, Tokyo, Japan). The obtained transparent gel was further characterized for its rheological behavior using a Brookfield rheometer R/S-CPS (Middleborough, MA, USA) with a parallel plate and plate gap of $1000 \mu \mathrm{m}$ and mucoadhesive property using rolling ball test as previously described [19].

\subsection{The Time-Killed Analysis Determination}

An in vitro modified time-killed analysis was performed to find out the killing time of S. aureus ATCC 25923 and the field isolates of $S$. aureus and S. epidermidis. The bacterial suspension was adjusted to $0.5 \mathrm{McF}$ arland standards. An exact amount of $0.8 \mathrm{~mL}$ of $0.5 \%$ lactic acid (LA) and $0.1 \mathrm{~mL}$ of bovine fetal serum were added into $0.1 \mathrm{~mL}$ of each bacterial suspension as well as the same amount of rice gel containing 5\% LA (LA-RG). The samples were ten-fold serial diluted in phosphate buffered saline (PBS). The viable bacteria were counted on PCA plates after incubating at $37^{\circ} \mathrm{C}$ for $24 \mathrm{~h}$. Time-killed analysis was studied at $30 \mathrm{~s}, 1,2,4,8$ and $32 \mathrm{~min}$.

\subsection{Detection of Bacterial Morphology by Scanning Electron Microscope (SEM)}

S. aurues ATCC 25923 in normal saline was incubated with $5 \%$ lactic acid at $37{ }^{\circ} \mathrm{C}$ for $8 \mathrm{~h}$. The bacterial sample was preserved using $2.5 \%$ glutaraldehyde in phosphate buffer $(\mathrm{pH} 7.4)$ at $4{ }^{\circ} \mathrm{C}$ for $24 \mathrm{~h}$. The specimen was dehydrated with graded ethanol and sputter coated with gold particles. The cell surface of the bacteria was examined under SEM (JEOL JSM 5410LV, Tokyo, Japan). The viable bacteria in NSS without lactic acid were used as a culture control. 


\subsection{Statistical Analysis}

All bacterial concentrations were normalized to CFU and then $\log 10$ transformed before analysis. Descriptive statistics for continuous variables were calculated. The comparison study of log 10 reductions of epidermal bacteria with the formulation was analyzed statistically by one-way analysis of variance (ANOVA) and differences among means were determined by Tukey's multiple comparison tests using the R statistical software (Rstudio, Boston, MA, USA). Probabilities less than 0.05 were considered significant.

\section{Results and Discussion}

\subsection{MIC and MBC Determination}

The antibacterial activity of lactic acid against Staphylococi was characterized by determining the MIC and MBC using the broth microdilution method. Values corresponding to the MIC and MBC of lactic acid against $S$. aureus and S. epidermidis are given in Table 1 . The results showed that the MIC of lactic acid against all tested strains was $0.5 \% v / v$. The MBC values for S. aureus and S. epidermidis were also $0.5 \% v / v$. These results clearly demonstrated that $S$. aureus ATCC 25923 and all staphylococci field isolates were susceptible to lactic acid. The ratio of lactic of MBC to MIC in the present study was similar to that previously reported [20]. The mode of action of bactericidal antibiotic is one for which the ratio of MBC to MIC is $\leq 4$ [21]. Thus, lactic acid has a bactericidal effect on S. aureus ATCC 25923, S. aureus and S. epidermidis. According to the previous studies, S. aureus were completely inhibited by $0.03 \%$ lactic acid [22,23]. Moreover, the quantitative antibacterial activity of lactic acid was also demonstrated with other gram positive bacteria: Listeria monocytogenes, Bacillus cereus and Bacillus megatherium [23]. The antibacterial efficacy of lactic acid is the result of the level of acid tolerance of an individual bacteria strain, $\mathrm{pH}$ and isomer of lactic acid [24,25].

Table 1. The MIC and MBC of lactic acid against staphylococcus species of three independent experiments performed in duplicate by broth microdilution test.

\begin{tabular}{lcc}
\hline \multicolumn{1}{c}{ Bacterial Strains } & MIC (\% v/v) & MBC (\% v/v) \\
\hline S. aureus ATCC 25923 & $0.5 \%$ & $0.5 \%$ \\
S. aureus (K14-001) & $0.5 \%$ & $0.5 \%$ \\
S. aureus (M15-166) & $0.5 \%$ & $0.5 \%$ \\
S. aureus (M16-066) & $0.5 \%$ & $0.5 \%$ \\
S. epidermidis (K14-004) & $0.5 \%$ & $0.5 \%$ \\
S. epidermidis (M15-028) & $0.5 \%$ & $0.5 \%$ \\
S. epidermidis (M15-031) & $0.5 \%$ & $0.5 \%$ \\
\hline
\end{tabular}

\subsection{Preparation and Characterization of Modified Rice Gel Containing Lactic Acid}

In the present study, raw rice powder from non-glutinous rice grains of Saohai varieties was prepared using the wet milling method (Figure 1A) [26]. As the raw rice powder was not soluble or could not be hydrated in water, the chemical modification of the starch structure in rice powder has therefore been suggested [27]. Chemical modified starch by carboxymethylated etherification has been widely used in pharmaceutical applications [28]. The color of the obtained raw rice powders and modified rice powders was pure white as shown in Figure 1B,C. The outer appearance of homogenous LA-RG prepared in the present study is shown in Figure 1D. It was found that the rice gels were not completely transparent. The previous study documented that gel turbidity occurs with the light scattering of particles entrapped inside the three-dimensional network of gel matrix [29]. In the present study, rice gel was used in the formulation in order to give it optimum viscosity and desirable rheological properties. It was found that the viscosity and $\mathrm{pH}$ of the formulation were approximately 0.007 Pas and $2.54 \pm 0.01$, respectively. Rheological behavior of the formulation was found to be a pseudoplastic and thixotropic non-Newtonian flow as shown in Figure 2. This result indicates the 
incomplete formation of the microstructural environment of the gel because of the lower shear stress. A prior study showed that the rheological properties of the rice gel prepared by thermal gelatinization resulted from amylose content and concentration of starch [30]. The adhesive test indicates that the obtained formulation had sufficient adhesive power to stop the rolling ball within $9.67 \pm 0.04 \mathrm{~cm}$. The interfacial force of the rice gel in the application area was influenced by adsorption, wetting and diffusion phenomena [31,32]. Increasing viscosity of the hydrogel influences the controlled release of drugs and is hardly removed by water. Therefore, an adhesive property is important for increasing time at the epithelium surface. In previous studies, rice gel was used as the gelling agent in the buccal anesthetic preparation of lidocaine [16] and oral mucoadhesive preparation of antineoplatic irinotecan [33].
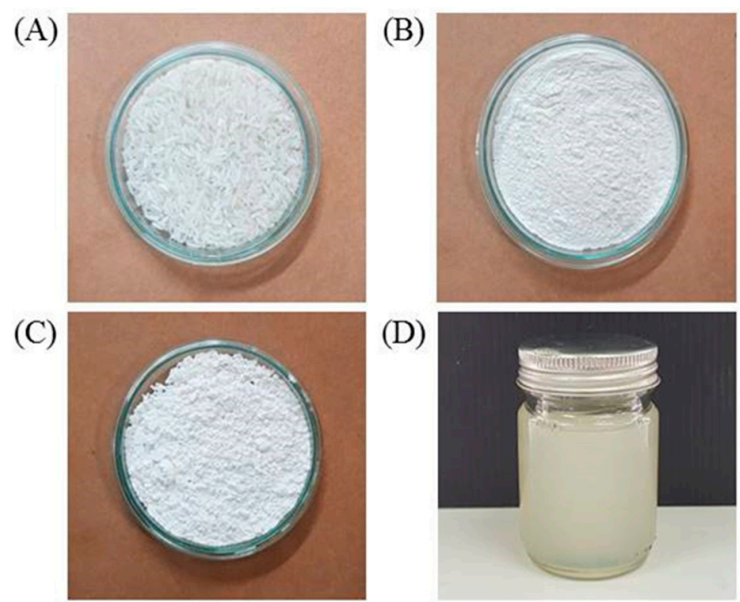

Figure 1. Outer appearance of (A) rice grains; (B) raw rice powders; (C) modified rice powders and (D) rice gel preparation.

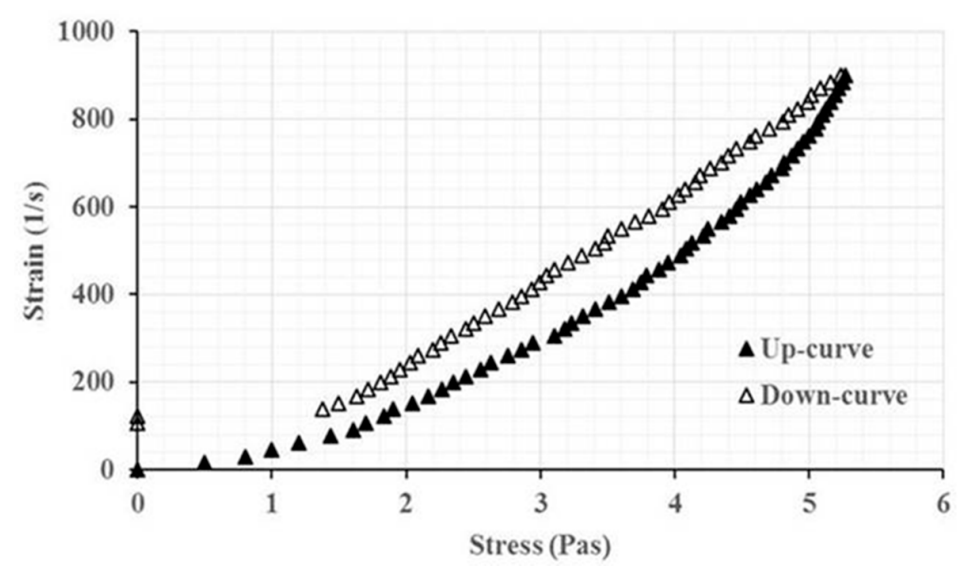

Figure 2. Rheogram of the modified rice gel containing 5\% v/v lactic acid (LA-RG).

\subsection{Time-Killed Analysis}

Time-killed analysis was performed to evaluate the complete killing time of $S$. aureus ATCC 25923, S. aureus and S. epidermidis as well as the kinetic killing of these organisms. The killing effect of LA and LA-RG is shown in Figures 3 and 4. The killing ability of LA and LA-RG on epidermal was time dependent. The very strong correlation between S. aureus ATCC $25923\left(R^{2}=0.9496\right)$ and S. epidermidis field strain $\left(R^{2}=0.9246\right)$ was observed on the killing ability of LA-RG. The rate of all bacteria reduction is first order kinetic with LA-RG. A linear equation of standard S. aureus ATCC $25923(k=-0.0834)$ was the most negative slope than that of both field strains including $S$. aureus $(k=-0.0631)$ and S. epidermidis $(k=-0.0057)$ (Figure 4). The reduction rate of LA on S. aureus ATCC 
25923, S. aureus field strain and S. epidermidis field strain showed 59.03\%, 34.31\% and 40.15\%; whereas, LA-RG showed $86.10 \%, 77.86 \%$ and $60.40 \%$, respectively. All epidermal bacteria were significantly reduced at $32 \mathrm{~min}$ and $1 \mathrm{~min}$ for LA\% and LA-RG in comparison with the initial bacteria count. The antibacterial property of the LA-RG was more effective than that of LA due to the concentration of lactic acid. Moreover, the diffusion and release of the lactic acid was controlled by the physicochemical properties of the gel formulation [34]. The results also indicated that the antiseptic rice gel of lactic acid has potential to prevent bovine mastitis. Moreover, as rice is nontoxic and has no irritation effect, the obtained preparation therefore has skin safety and also an emollient property suitable for topical application [14]. Additionally, there is a skin wound healing promotion effect of polysaccharide gel from Durio zibethinus Murr, previousl reported in mammal skins [35,36]. The efficacy of polysaccharide gel from Tremella fuciformis and Auricularia auricular was also studied for wound healing in pig skin [37]. Therefore, using natural polysaccharide rice gel is considered to promote rapid healing as well as improve skin health.
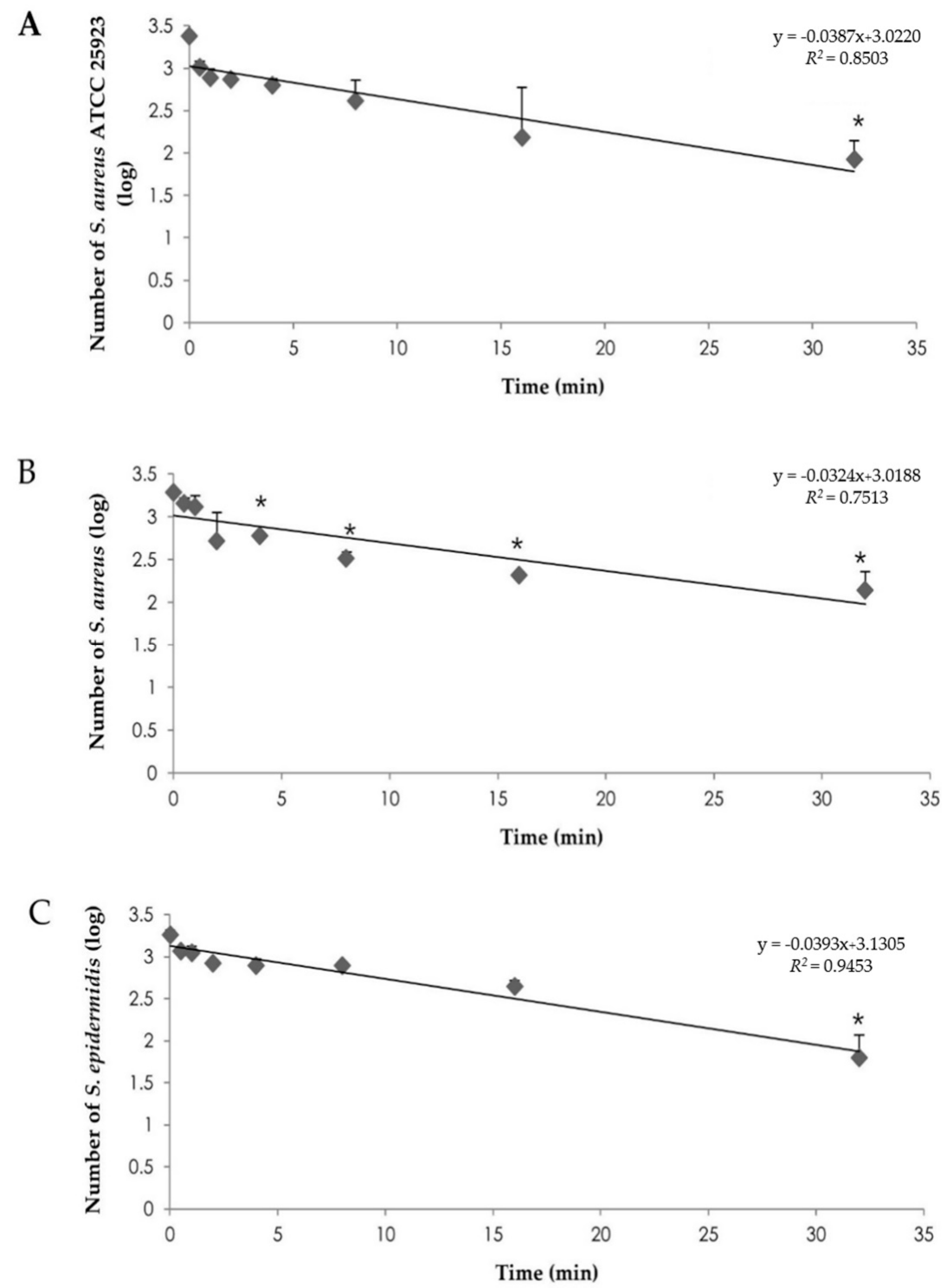

Figure 3. The killing rate of S. aureus ATCC 25923 (A); S. aureus field strain (B) and S. epidermidis field straind $(\mathbf{C})$ with LA against bovine teat skin bacteria. Vertical bars represented the mean \pm S.D. The line shown is the graph of the linear equation. Asterisk $\left(^{*}\right)$ means the significant differences of bacterial count at $p \leq 0.05$. 
A

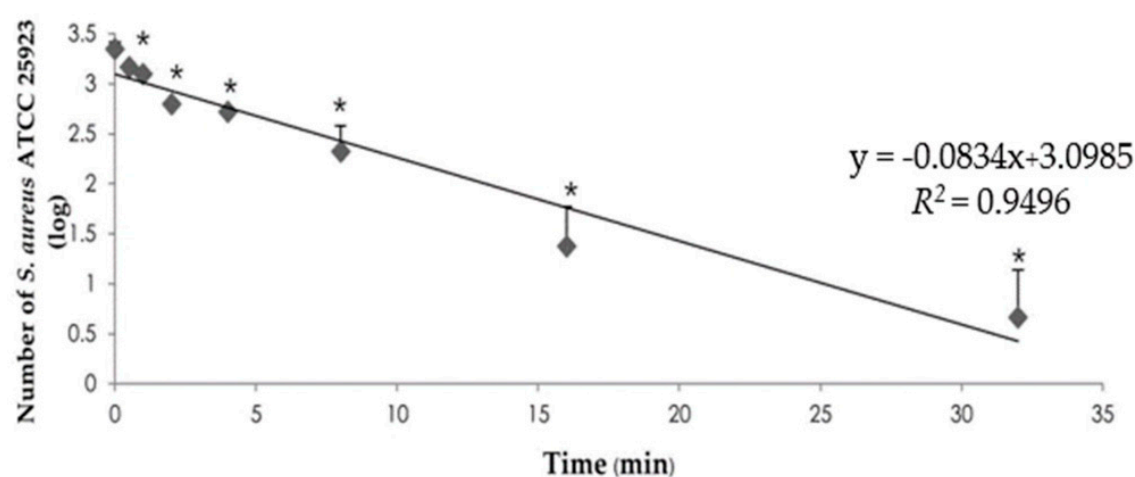

B

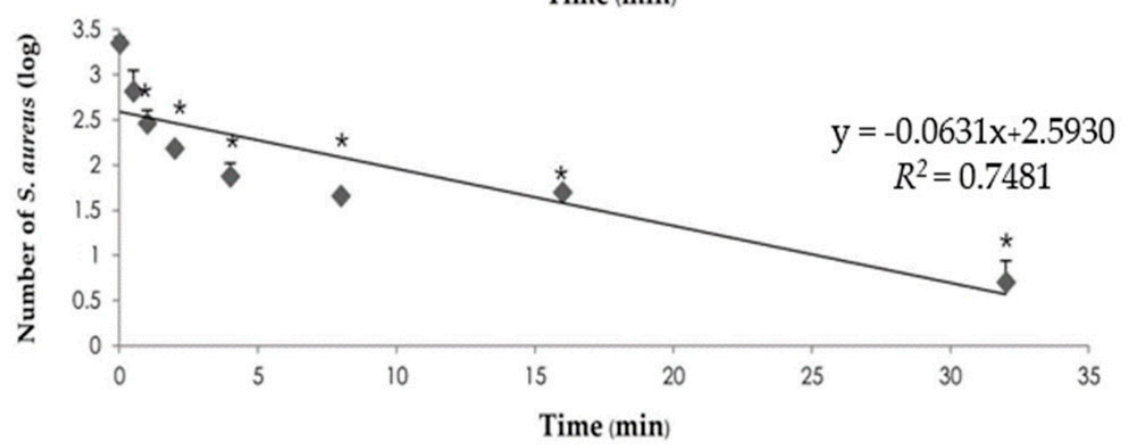

C

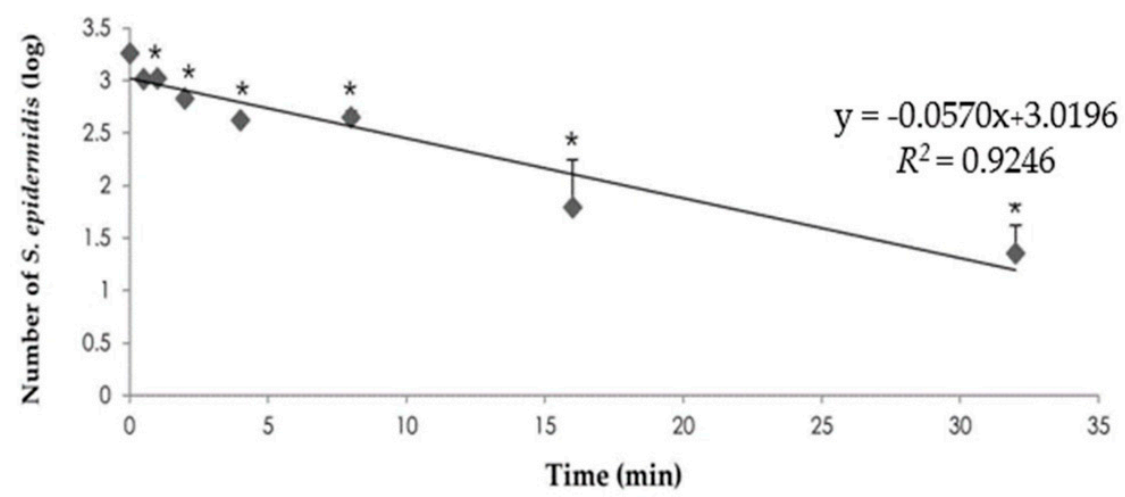

Figure 4. The killing rate of S. aureus ATCC 25923 (A); S. aureus field strain (B) and S. epidermidis field straind (C) with LA-RG against bovine teat skin bacteria. Vertical bars represented the mean \pm S.D. The line shown is the graph of the linear equation. Asterisk $\left(^{*}\right)$ means the significant differences of bacterial count at $p \leq 0.05$.

\subsection{Bacterial Morphology}

An appearance under SEM of viable S. aureas in NSS without lactic acid was shown in Figure 5A. The untreated cells demonstrated a spherical shape and smooth cell surfaces. The non-viable $S$. aureas incubated with $5 \% v / v$ of lactic acid is shown in Figure 5B. After incubation, S. aureas underwent significant morphological changes from coccoid to atypical form. All of the treated cells clearly displayed flaccid and rough membrane structures. The mechanism of antibacterial activity of lactic acid against gram-positive bacteria is not yet fully understood. However, the antibacterial activity of lactic acid is also found to be apparently related to acidity in the medium because the bacteria stress is promoted from the intracellular accumulation of acid anions. The effect of the low $\mathrm{pH}$ of lactic acid on the outer structure of bacterial membrane disintegration is widely known [38,39]. Moreover, there are some detailed reports that provide insight into the mechanism of lactic acid's disruptive action on the bacterial cytoplasmic membrane $[13,40]$. 


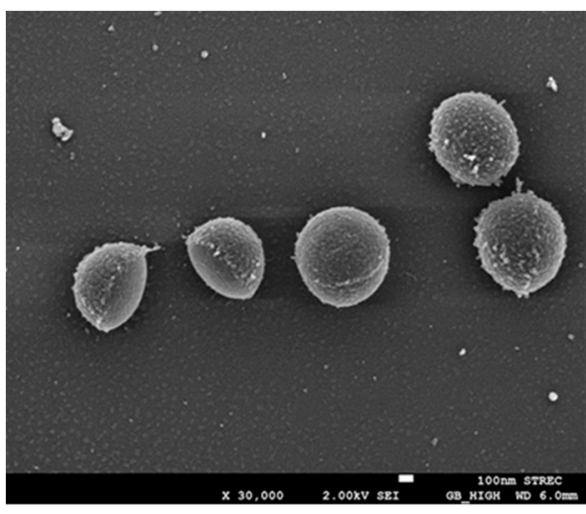

(A)

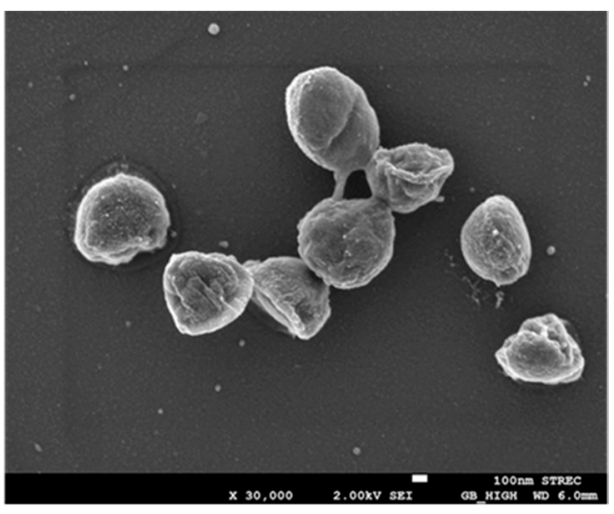

(B)

Figure 5. Scanning electron micrographs of S. aureus after incubation at $37^{\circ} \mathrm{C}$ for $8 \mathrm{~h}$; (A) Viable cells $(30,000 \times)$ in NSS without lactic acid; (B) Non-viable cells $(30,000 \times)$ with $5 \% v / v$ lactic acid.

\section{Conclusions}

Rice gel containing a lethal concentration $(5 \% v / v)$ of lactic acid was successfully developed. The developed antiseptic rice gel possesses a killing effect on some epidermal bacteria. The abnormal cell surface of the treated bacteria demonstrated by SEM confirms that the antiseptic rice gel containing lactic acid possesses high potential bactericidal activity. Our results demonstrate that the lactic acid gel may provide a promising teat antiseptic product for controlling staphylococcal mastitis in dairy cows. The modified rice starch is a promising natural biodegradable agent that is suitable for gel formulation as a sanitizer for controlling infection from skin pathogens. This nontoxic natural product can be an attractive alternative remedy in routine use for udder hygiene, since the use of chemical agents and antibiotics in livestock will be restricted in the near future.

Author Contributions: The preparation of the rice gel presented in this work was prepared by S.O. The laboratory investigation was performed by R.C. and R.M. The data analysis was analyzed by R.C. and K.N.L. The manuscript was written by R.C., S.O., and R.M. R.M., S.O., S.P. and K.A. worked as a project administrator.

Funding: The authors are grateful for the financial support of the Agriculture Research Development Agency Thailand (Foundation Number: CRP 5905010750).

Conflicts of Interest: The authors declare no conflict of interest

\section{References}

1. Nagase, N.; Sasaki, A.; Yamashita, K.; Shimizu, A.; Wakita, Y.; Kitai, S.; Kawano, J. Isolation and species distribution of staphylococci from animal and human skin. J. Vet. Med. Sci. 2002, 64, 245-250. [CrossRef] [PubMed]

2. Matsui, K.; Nishikawa, A.; Suto, H.; Tsuboi, R.; Ogawa, H. Comparative study of Staphylococcus aureus isolated from the lesional and non-lesional skin of atopic dermatitis. Microbiol. Immunol. 2000, 44, 945-947. [CrossRef] [PubMed]

3. Stryjewski, M.E.; Corey, G.R. Methicillin-resistant Staphylococcus aureus: An evolving pathogen. Clin. Infect. Dis. 2014, 58, 10-19. [CrossRef] [PubMed]

4. Ünal, N.; Yıldırım, M. Antibiotic resistance profiles of staphylococci species isolated from milk, teat skins and noses mucous of cows. Kafkas Univ. Vet. Fak. Derg. 2010, 16, 389-396. [CrossRef]

5. Ajariyakhajorn, K.; Samngamnim, S.; Boonserm, T.; Inchaisri, C.; Thirapatsakun, T.; Farnsworth, R.J. Mastitis in small dairy holders of Nakhonpathom province, Thailand. In Proceedings of the 11th International Symposium of the World Association of Veterinary Laboratory Diagnosticians and OIE Seminar on Biotechnology, Bangkok, Thailand, 3 November 2003; pp. 122-123.

6. Boonyayatra, S.; Chaisri, W. Incidence and prevalence of subclinical mastitis in small holder dairy farms of Chiang Mai province, Thailand. CMV J. 2004, 2, 25-30. 
7. Pumipuntu, N.; Kulpeanprasit, S.; Santajit, S.; Witawat, T.; Thida, K.; Woranich, H.; Nitaya, I. Screening method for Staphylococcus aureus identification in subclinical bovine mastitis from dairy farms. Vet. World 2017, 10, 721-726. [CrossRef] [PubMed]

8. Thorberg, B.M.; Danielsson-Tham, M.L.; Emanuelson, U.; Persson Waller, K. Bovine subclinical mastitis caused by different types of coagulase-negative staphylococci. J. Dairy Sci. 2009, 92, 4962-4970. [CrossRef] [PubMed]

9. Björk, S.; Båge, R.; Kanyima, B.M.; André, S.; Nassuna-Musoke, M.G.; Owiny, D.O.; Persson, Y. Characterization of coagulase negative staphylococci from cases of subclinical mastitis in dairy cattle in Kampala, Uganda. Irish Vet J. 2014, 67, 12. [CrossRef] [PubMed]

10. Burton, M.; Cobb, E.; Donachie, P.; Judah, G.; Curtis, V.; Schmidt, W.P. The effect of handwashing with water or soap on bacterial contamination of hands. Int. J. Environ. Res. Public Health 2011, 8, 97-104. [CrossRef] [PubMed]

11. Russell, A.D. Mechanisms of bacterial resistance to biocides. Int. Biodeterior. Biodegrad. 1995, 36, $247-265$. [CrossRef]

12. Alsaheb, R.A.A.; Aladdin1, A.; Othman, N.Z.; Malek, R.A.; Leng, O.M.; Aziz, R.; Enshasy, H.A.E. Lactic acid applications in pharmaceutical and cosmeceutical industries. J. Chem. Pharm. Res. 2015, 7, 729-735.

13. Wang, C.; Chang, T.; Yang, H.; Cui, M. Antibacterial mechanism of lactic acid on physiological and morphological properties of Salmonella Enteritidis, Escherichia coli and Listeria monocytogenes. Food Control 2015, 47, 231-236. [CrossRef]

14. Andersen, F.A. Final report on the safety assessment of glycolic acid, ammonium, calcium, potassium and sodium glycolates, methyl, ethyl, propyl and butyl glycolates and lactic acid, ammonium, calcium, potassium, sodium and TEA-lactates, methyl, ethyl, isopropyl and butyl lactates and lauryl, myristyl and cetyl lactates. Int. J. Toxicol. 1998, 17, 1-241.

15. Rehman, K.; Zulfakar, M.H. Recent advances in gel technologies for topical and transdermal drug delivery. Drug Dev. Ind. Pharm. 2014, 40, 433-440. [CrossRef] [PubMed]

16. Okonogi, S.; Kaewpinta, A.; Yotsawimonwat, S.; Khongkhunthian, S. Preparation and characterization of lidocaine rice gel for oral application. Drug Discov. Ther. 2015, 9, 397-403. [CrossRef] [PubMed]

17. Okonogi, S.; Kaewpinta, A.; Khongkhunthian, S.; Yotsawimonwat, S. Effect of rice variety on the physicochemical properties of the modified rice powders and their derived mucoadhesive gels. Drug Discov. Ther. 2015, 9, 221-228. [CrossRef] [PubMed]

18. Ramalivhana, J.N.; Obi, C.L.; Samie, A.; Iweriebor, B.C.; Uaboi-Egbenni, P.; Idiaghe, J.E.; Momba, M.N.B. Antibacterial activity of honey and medicinal plant extracts against gram-negative microorganisms. Afr. J. Biotechnol. 2014, 13, 616-625. [CrossRef]

19. Ren, C.; Fang, L.; Ling, L.; Wang, Q.; Liu, S.; Zhao, L.G.; He, Z. Design and evaluation of indapamide transdermal patch. Int. J. Pharm. 2009, 370, 129-135. [CrossRef] [PubMed]

20. Kaloud, j.; Pokludova, L.; Novotna, R.; Cizek, A. Evaluation by conductance assay of shiga toxin producing Escherichia coli (STEC) O157 and O26 and their sensitivity to selected disinfectants. Acta Vet. Brno. 2003, 72, 101-109. [CrossRef]

21. Haas, W.; Pillar, C.M.; Hesje, C.K.; Sanfilippo, C.M.; Morris, T.W. Bactericidal activity of besifloxacin against staphylococci, Streptococcus pneumoniae and Haemophilus influenza. J. Antimicrob. Chemother. 2010, 65, 1441-1447. [CrossRef] [PubMed]

22. Abu-Ghazaleh, B.M. Effects of ascorbic acid, citric acid, lactic acid, $\mathrm{NaCl}$, potassium sorbate and Thymus vulgaris extract on Staphylococcus aureus and Escherichia coli. Afr. J. Microbiol. Res. 2013, 7, 7-12.

23. Stanojević-Nikolić, S.; Dimić, G.; Mojović, L.; Pejin, J.; Djukić-Vuković, A.; Kocić-Tanackov, S. Antimicrobial activity of lactic acid against pathogen and spoilage microorganisms. J. Food Process. Preserv. 2016, 40, 990-998. [CrossRef]

24. Tachedjian, G.; Aldunate, M.; Bradshaw, C.S.; Cone, R.A. The role of lactic acid production by probiotic Lactobacillus species in vaginal health. Res. Microbiol. 2017, 168, 782-792. [CrossRef] [PubMed]

25. Pundir, R.K.; Jain, P. Evaluation of five chemical food preservatives for their antibacterial activity against bacterial isolates from bakery products and mango pickles. J. Chem. Pharm. Res. 2011, 3, $24-31$.

26. Okonogi, S.; Khongkhunthien, S.; Jaturasitha, S. Development of mucoadhesive buccal films from rice for pharmaceutical delivery systems. Drug Discov. Ther. 2014, 8, 262-267. [CrossRef] [PubMed] 
27. Neelam, K.; Vijay, S.; Lalit, S. Various techniques for the modification of starch and the applications of its derivatives. IRJP 2012, 3, 25-31.

28. Lawal, O.S.; Lechner, M.D.; Kulicke, W.M. Single and multi-step carboxymethylation of water yam (Dioscorea alata) starch: Synthesis and characterization. Int. J. Biol. Macromol. 2008, 42, 429-435. [CrossRef] [PubMed]

29. Lau, M.H.; Tang, J.; Paulson, A.T. Texture profile and turbidity of gellan/gelatin mixed gels. Food Res. Int. 2000, 33, 665-671. [CrossRef]

30. Blazek, J.; Gilbert, E.P. Effect of enzymatic hydrolysis on native starch granule structure. Biomacromolecules 2010, 11, 3275-3289. [CrossRef] [PubMed]

31. Smart, J.D. The basics and underlying mechanisms of mucoadhesion. Adv. Drug Deliv. Rev. 2005, 3, 1556-1568. [CrossRef] [PubMed]

32. Mirza, M.A.; Ahmad, S.; Mallick, M.N.; Manzoor, N.; Talegaonkar, S.; Iqbal, Z. Development of a novel synergistic thermosensitive gel for vaginal candidiasis: An in vitro, in vivo evaluation. Colloids Surf. B Biointerfaces 2013, 103, 275-282. [CrossRef] [PubMed]

33. Ahmed, A.B.; Bhaduri, I. Development and evaluation of Assam Bora rice starch-carbopol based oral mucoadhesive gel of irinotecan for mouth cancer. J. Pharm. Sci. Res. 2017, 9, 1139-1146.

34. Verma, A.; Singh, S.; Kaur, R.; Jain, U.K. Topical gels as drug delivery systems: A review. Int. J. Pharm. Sci. Rev. Res. 2013, 23, 374-382.

35. Chansiripornchai, P.; Pongsamart, S. Treatment of infected open wounds on two dogs using a film dressing of polysaccharide extracted from the hulls of durian (Durio zibethinus Murr.): Case report. Thai J. Vet. Med. 2008, 38, 55-61.

36. Chansiripornchai, P.; Pramatwinai, C.; Rungsipipat, A. The efficiency of polysaccharide gel extracted from fruit-hulls of durian (Durio zibethinus L.) for wound healing in pig skin. Acta Hortic. 2005, 679, 37-43. [CrossRef]

37. Khamlue, R.; Naksupan, N.; Ounaroon, A.; Saelim, N. Skin wound healing promoting effect of polysaccharides extracts from Tremella fuciformis and Auricularia auricula on the ex-vivo porcine skin wound healing model. In Proceedings of the 2012 4th International Conference on Chemical, Biological and Environmental Engineering, Phket, Thailand, 1-2 September 2012; Volume 43, pp. 93-98.

38. Russell, J.B. Another explanation for the toxicity of fermentation acids at low $\mathrm{pH}$ : Anion accumulation versus uncoupling. J. Appl. Microbiol. 1992, 73, 363-370. [CrossRef]

39. Warnecke, T.; Gill, R.T. Organic acid toxicity, tolerance and production in Escherichia coli biorefining applications. Microb. Cell Fact. 2005, 4, 25-33. [CrossRef] [PubMed]

40. Alakomi, H.L.; Skyttä, E.; Saarela, M.; Mattila-Sandholm, T.; Latva-Kala, K.; Helander, I.M. Lactic acid permeabilizes gram-negative bacteria by disrupting the outer membrane. Appl. Environ. Microbiol. 2000, 66, 2001-2005. [CrossRef] [PubMed]

(C) 2018 by the authors. Licensee MDPI, Basel, Switzerland. This article is an open access article distributed under the terms and conditions of the Creative Commons Attribution (CC BY) license (http://creativecommons.org/licenses/by/4.0/). 